\title{
Comparison of Fatty Acid Profile of Edible Tissues of Wild Terrestrial Snail (Helix lucorum L. 1758) Collected in Two Province (Adana and Sinop)
}

\author{
Mustafa Göçer, İlkan Ali Olgunoğlu* \\ Department of Aquaculture and Fisheries Program, Kahta Vocational Training School, Adiyaman University, 02400 Adlyaman, Turkey
}

\section{A R T I C LE INFO}

\section{Research Articles}

Received 03 February 2018

Accepted 05 June 2018

Keywords:

Eatable texture

Helix lucorum

Fatty acid

Turkey

Snail

${ }^{*}$ Corresponding Author:

E-mail: ilkanali@yahoo.com

\begin{abstract}
A B S T R A C T
The aim of the present study is to compare the crude protein, fat content and fatty acids concentration of snail meat (Helix lucorum Linnaeus, 1758) obtained from Adana and Sinop Province (including 30 snail meat for both region) in Turkey. They were not statistically significant differences in fatty acid profile between two groups. But, in contrast to previous reports, may be due to geographical variation, the results show that the examined snails demonstrated a high content of fat that is between $3.74 \%$ and $4.20 \%$. The analyses also indicated that snail meat from Adana province was richer in protein and fat content than Sinop province. In fatty acid composition for both region, monounsaturated fatty acid fraction (MUFA) was dominant followed by saturated fatty acid (SFA) and polyunsaturated fatty acid (PUFA). The ratio of $n-3 / n-6$ and the content of PUFAs were found to be better in Adana province than Sinop. However, for both region, the ratio of PUFA/SFA was lower in H. lucorum than those recommended for nutritional.
\end{abstract}

Türk Tarım - Gıda Bilim ve Teknoloji Dergisi, 6(7): 877-880, 2018

Türkiye'de İki İlden (Adana ve Sinop) Toplanan Doğal Karasal Salyangoz (Helix lucorum L. 1758)'un Yenilebilir Dokularındaki Yağ Asidi Profilinin Karşılaştırılması

M A K A L E B İ L G İ S İ

Araştırma Makalesi

Geliş 03 Şubat 2018

Kabul 05 Haziran 2018

\section{Anahtar Kelimeler:}

Yenilebilir doku

Helix lucorum

Yağ asidi

Türkiye

Salyangoz

"Sorumlu Yazar:

E-mail: ilkanali@yahoo.com
Ö Z

Bu çalışmanın amacı, Türkiye'de Adana ve Sinop İli'nden (her iki bölge için 30 salyangoz eti) elde edilen salyangoz etinin (Helix lucorum Linnaeus, 1758) ham protein, yağ içeriği ve yağ asitleri konsantrasyonunu karşılaştırmaktır. Yağ asidi profilinde iki grup arasında istatistiksel olarak farklılıklar bulunmamıştır. Ancak, daha önceki çalışmaların aksine incelenen salyangozların \%3,74 ile \%4,20 arasında yüksek bir yağ içerine sahip olduğu; bu farklılığın coğrafi farklılıklardan kaynaklanıyor olabileceği sonucuna varılmıştır. Analiz sonuçları, Adana ilinden elde edilen salyangoz etinin protein ve yağ içeriğinin, Sinop ilinden elde edilenden daha zengin olduğunu ortaya koymuştur. Her iki bölgeye ait salyangoz etinin yağ asidi bileşiminde, en fazla tekli doymamış yağ asidi oranı (MUFA) tespit edilmiş bunu doymuş yăg asidi (SFA) ve çoklu doymamış yăg asidi (PUFA) izlemiştir. Adana iline ait salyangozlarda n- $3 / n-6$ ve PUFA içeriğinin oranın, Sinop iline göre daha iyi olduğu tespit edilmiştir. Bununla birlikte, H. lucorum'da her iki bölge için PUFA/SFA oranı, beslenme için önerilen oranlardan daha düşük bulunmuştur. 


\section{Introduction}

Molluscs are an excellent source of protein and lipid which are characterized by a great variety of fatty acids especially in major lipid classes (Ekin et al., 2015). Mollusca contain at least 80.000 species and the Gastropoda is the only class of molluscs which have invaded land. Snails are members of Mollusca which are the second largest phylum of the animal kingdom (Zarai et al., 2011; Lukong et al., 2012). Snails are processed by different methods for consumption and they have been consumed since prehistoric times. While snail meat are mostly eaten in great quantities by many European countries, never consumed in Turkey. Snail meats are important export item for Turkey. They are exported by processed or fresh by Fishery Products Processing Plants to France, Italy, Greece, Spain, Germany, Hungary, USA, South America and to Far East countries such as Japan and China (Saglam and Gokhan, 2006; Olgunoglu and Olgunoglu, 2008; Baki, 2010; Uboh et al., 2014; Y1ldırım et al., 2014). Some economically important edible snail species are Helix aspersa, Helix pomatia, Helix lucorum, Helix aperta (Born), Eobania vermiculata (Miller). Among them Helix pomatia is the most popular species. Helix lucorum is less valuable edible terrestrial snail (Abdulmawjood and Bülte, 2001; Baltic, 2005; Olgunoglu and Olgunoglu, 2008). Helix lucorum is well adapted to human-modified landscapes such as gardens, parks, and arable land (Mumladze, 2013). It is an abundant snail in Turkey because of country's topographical structure, favorite weather and environmental condition, therefore it is also known as Turkish or Turkey snail (Olgunoglu and Olgunoglu, 2009; Çelik et al., 2017).

Recently, there has been a considerable amount of research related to chemical composition and fatty acids (Olgunoglu et al., 2011; Haider et al., 2015; Pasdaran et al., 2017a; Pasdaran et al., 2017 b; Göçer et al., 2018). Therefore, this study focused on Helix lucorum from the two province of the Turkey in order to compare their proteins and fatty acid profiles prior to their consumption.

\section{Material and Methods}

\section{Materials}

Snail samples were obtained from Sinop province (which is located in the Western Black Sea Region of Turkey) and Adana province (which is located in the Mediterranean Region of Turkey) in April and May 2017 (Figure 1). Immediately, after collection, snails were stored in a container, and transferred to the laboratory, where the shells and intestines were removed carefully as manuel to obtain edible parts of snail for analysis. After that, snails were kept at $-18^{\circ} \mathrm{C}$ until chemical analysis. The total number of samples was 30 for each province.

\section{Methods}

The crude protein analysis of snail meat samples was carried out according to the Kjeldahl Method and the fat was determined according to the Acid Hydrolysis Soxtec System (AOAC,1995).

IUPAC Methods II. D. 19 (1979) was used to prepare the methyl esters of fatty acids of snail samples. To determine the fatty acid composition of samples, analyses were done by using a Perkin Elmer Autosystem XL Gas Chromotography and Flame Ionization Detector (FID) equipment and a Supelco 2330 fused silica capillary column (30 mx $0.25 \mathrm{~mm} \times 0.20 \mu \mathrm{m}$ film thickness).

\section{Statistical Analyses}

For data analysis, The independent-samples t test was used to evaluate the difference between the means of two independent groups. The mean values were obtained from 3 experiments and reported as $\mathrm{X} \pm \mathrm{SD}$. Significance of differences was defined at $\mathrm{P} \leq 0.05$.

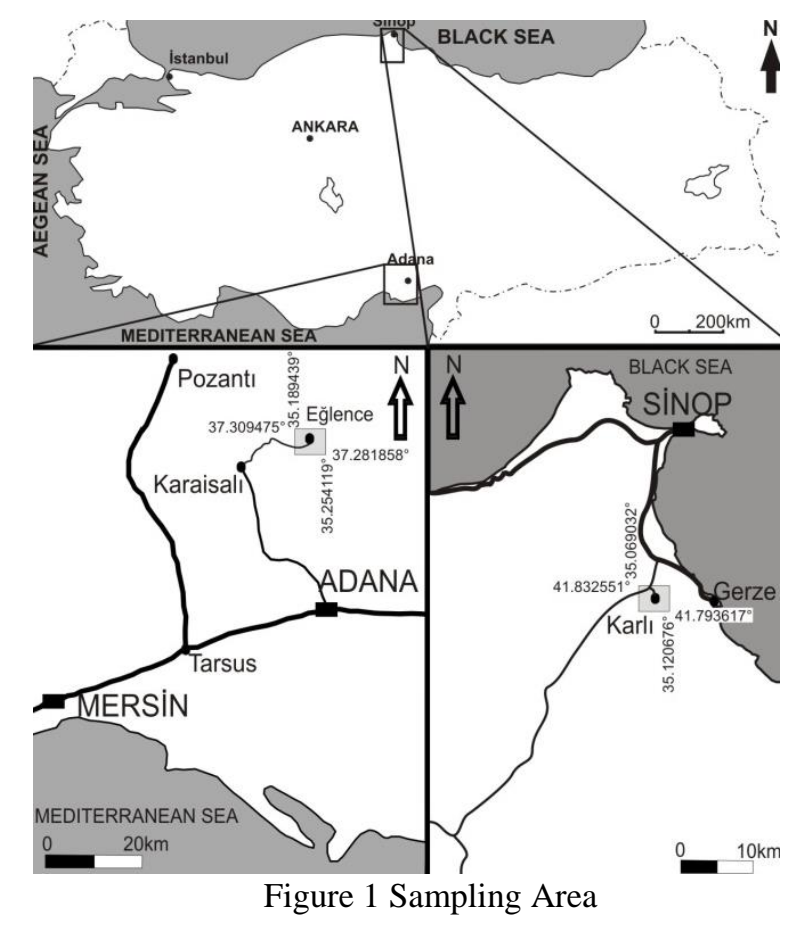

\section{Results and Discussion}

The quantity of the crude protein and fat contents of wild terrestrial snail (Helix lucorum) collected in two province (Adana and Sinop) from Turkey are shown in Table 1.

Table 1 The quantity of the crude protein and fat contents of Helix lucorum

\begin{tabular}{l|cc}
\hline \multicolumn{1}{c|}{ Parameters } & $\begin{array}{c}\text { Snail from } \\
\text { Adana Province }\end{array}$ & $\begin{array}{c}\text { Snail from } \\
\text { Sinop Province }\end{array}$ \\
\hline Fat $(\%)$ & $4.20 \pm 0.16$ & $3.74 \pm 0.15$ \\
Protein $(\%)$ & $10.28 \pm 0.10$ & $8.77 \pm 0.18$ \\
\hline
\end{tabular}

Mean values in the same row having the same superscript are not significantly different $(\mathrm{P}>0.05)$. Values are shown as means $\pm \mathrm{SD}$

The quantity of the crude protein and fat contents of snail meat from Adana province was found to be higher than the snail meat from Sinop province $(\mathrm{P}>0.05)$. The protein content of H.lucorum ranged between $8.77 \%$ and $10.28 \%$. The fat content was identified to differ between $3.74 \%$ and $4.20 \%$. The amount of fat content in two snails species recorded by Uboh et al. (2014) varied from 2.40 (Archachatina marginata) to 2.85 (Achatina achatina). Some studies on different snail species showed that the fat 
content of snail meat varies from $0.41 \%$ to $2.66 \%$ (Gül and Fenercioglu,1992; Özogul et al., 2005; Fagbuaro et al., 2006; Milinsk et al., 2006; Olgunoglu and Olgunoglu, 2009).

Table 2 The profiles and percentage composition of 23 different fatty acids in Helix lucorum

\begin{tabular}{|c|c|c|}
\hline Fatty Acids & $\begin{array}{l}\text { Snail from Adana } \\
\text { Province } \%\end{array}$ & $\begin{array}{c}\text { Snail from Sinop } \\
\text { Province } \%\end{array}$ \\
\hline $\mathrm{C} 4: 0$ & $1.00^{\mathrm{a}} \pm 0.00$ & $0.58^{\mathrm{a}} \pm 0.00$ \\
\hline C8:0 & $0.37^{\mathrm{a}} \pm 0.00$ & $0.31^{\mathrm{a}} \pm 0.00$ \\
\hline C10:0 & $0.47^{\mathrm{a}} \pm 0.00$ & $0.85^{\mathrm{a}} \pm 0.00$ \\
\hline C12:0 & $2.25^{\mathrm{a}} \pm 0.28$ & $2.36^{\mathrm{a}} \pm 0.57$ \\
\hline C14:0 & $0.70^{\mathrm{a}} \pm 0.11$ & $0.44^{\mathrm{a}} \pm 012$ \\
\hline C16:0 & $13.63^{\mathrm{a}} \pm 0.36$ & $11.74^{\mathrm{a}} \pm 0.40$ \\
\hline $\mathrm{C} 17: 0$ & $1.27^{\mathrm{a}} \pm 0.11$ & $1.06^{\mathrm{a}} \pm 0.11$ \\
\hline C20:0 & $5.51^{\mathrm{a}} \pm 0.28$ & $4.53^{\mathrm{a}} \pm 0.29$ \\
\hline $\mathrm{C} 21: 0$ & $2.21^{\mathrm{a}} \pm 0.11$ & $3.39^{\mathrm{a}} \pm 0.01$ \\
\hline $\mathrm{C} 22: 0$ & $4.61^{\mathrm{a}} \pm 0.11$ & $3.51^{\mathrm{a}} \pm 0.11$ \\
\hline$\sum$ SFA & 32.02 & 28.77 \\
\hline C14:1 & $0.63^{\mathrm{a}} \pm 0.01$ & $0.73^{\mathrm{a}} \pm 0.09$ \\
\hline C15:1 & $0.62^{\mathrm{a}} \pm 0.01$ & $0.87^{\mathrm{a}} \pm 0.01$ \\
\hline $\mathrm{C} 17: 1$ & $0.68^{\mathrm{a}} \pm 0.01$ & $0.46^{\mathrm{a}} \pm 0.01$ \\
\hline C18:1n-9 & $29.71^{\mathrm{a}} \pm 0.11$ & $31.09^{\mathrm{a}} \pm 0.05$ \\
\hline C20:1 & $0.59^{\mathrm{a}} \pm 0.01$ & $0.43^{\mathrm{a}} \pm 0.01$ \\
\hline C22:1n-9 & $2.09^{a} \pm 0.05$ & $2.68^{\mathrm{a}} \pm 0.04$ \\
\hline $\mathrm{C} 24: 1$ & $2.08^{\mathrm{a}} \pm 0.04$ & $1.28^{\mathrm{a}} \pm 0.16$ \\
\hline$\sum$ MUFA & 36.40 & 37.54 \\
\hline C18:2n-6 & $4.31^{\mathrm{a}} \pm 0.12$ & $3.55^{\mathrm{a}} \pm 0.98$ \\
\hline$C 18: 3 n-6$ & $0.52^{\mathrm{a}} \pm 0.01$ & $0.44^{\mathrm{a}} \pm 0.01$ \\
\hline$C 20: 3 n-6$ & $0.49^{\mathrm{a}} \pm 0.05$ & $0.60^{\mathrm{a}} \pm 0.05$ \\
\hline C20:5n-3(EPA) & $1.55^{\mathrm{a}} \pm 0.02$ & $0.20^{\mathrm{a}} \pm 0.01$ \\
\hline $\mathrm{C} 22: 2$ & $0.86^{\mathrm{a}} \pm 0.03$ & $0.95^{\mathrm{a}} \pm 0.02$ \\
\hline C22:6n-3 (DHA) & $1.83^{\mathrm{a}} \pm 0.02$ & $1.81^{\mathrm{a}} \pm 0.01$ \\
\hline$\sum$ PUFA & 9.56 & 7.55 \\
\hline$\sum \mathrm{n} 3$ & 3.38 & 2.01 \\
\hline$\sum \mathrm{n} 6$ & 5.32 & 4.59 \\
\hline $\mathrm{n} 3 / \mathrm{n} 6$ & 0.63 & 0.44 \\
\hline PUFA/SFA & 0.30 & 0.26 \\
\hline
\end{tabular}

In a study on Roman snail's meat (Helix pomatia) from different regions of Turkey, the content of crude protein was recorded as $12.96 \%$ (Ikauniec et al., 2014), in another study on H. Lucorum, protein content was found between $10.22 \%$ and $11.49 \%$ respectively (Olgunoglu and Olgunoglu, 2008; 2009). It was also reported that the amount of protein in snail meat could varies from $9.50 \%$ to $12.56 \%$ depending on feed intake (Milinsk et al., 2006). Citil et al. (2014) stated that in their study for Helix aspersa the quantity of protein was found between $14.12 \%$ and $12.31 \%$ in autumn and spring. As a whole in the present study the protein content was found similar while content of lipid was identified higher than those reported previously for some snail species. It was reported that the level of protein and fat content of species greatly varies during the catching seasons and changed in environmental conditions (Sutharshiny and Sivashanthini, 2011). Therefore this difference may be due to geographical variation and the fat content is also influenced by seasonal variations, age and maturity (Citil et al.(2014). The profiles and percentage composition of 23 different fatty acids in Helix lucorum are presented in Table 2. The fatty acids analyzed were grouped as saturated fatty acids (SFAs), monounsaturated fatty acids (MUFAs) and polyunsaturated fatty acid (PUFAs). In the present study, in both region, MUFA was the highest followed by SFA and PUFA. The major saturated fatty acids (SFA) in Helix lucorum from two province was palmitic acid (16:0) followed by arachidic acid (C20:0) and behenic acid $\mathrm{C} 22: 0$. The caprylic acid (C8:0) was the least SFA in the samples for two province. The total SFA values in snail meat from Adana (32.02) was found higher than from Sinop (28.77) $(\mathrm{P}>0.05)$. The Major three MUFAs in both samples consisted of C18:1 n-9, C22:1n9 and $\mathrm{C} 24: 1$. Oleic acid (C18:1 n-9) was the primary monounsaturated fatty acid for the both snail meat. The total MUFA percentage in snail meat from Sinop (37.54) was higher than snail meat from Adana (36.40) $(\mathrm{P}>0.05)$.

Mean values in the same row having the same superscript are not significantly different $(\mathrm{P}>0.05)$. Values are shown as means $\pm \mathrm{SD}$

Among the polyunsaturated fatty acids in $H$. lucorum for both region, linoleic acids (C18:2 n-6) were found to be prevailed among the n-6 acids; docosahexaenoic acid (C22:6n-3) were dominant among the n-3 acids, Similar results were reported in some studies on different snails species. For example, Özogul et al. (2005) stated that the major fatty acids determined in the snail Helix pomatia from the region of the south of the Turkey were C16:0 (12\%) C18:0 (19\%), C22:0 (7\%), C18:1n-9 (17\%), and C18:2n-6 (16\%). According to Citil et al., (2014) the highest fatty acids of Helix aspersa are C18:2n-6 linoleic acid, C18:1n-9 oleic acid, C20:4 arachidonic and C16:0 palmitic acid, respectively. The principal acids in PUFA group were reported to be linoleic acid (C18:2), eicosapentaenoic acid (C20:5, EPA) and docosahexaenoic acid (C22:6, DHA) (Osibona et al., 2009; Olgunoglu, 2013). Our results are in agreement with the results reported on grouping of PUFAs.

The ratios of PUFA/SFA and n-3/n- 6 are widely used as indices to assess the nutritional value of fat for human consumption. According to some nutritional recommendations the PUFA/SFA ratio in human diets should be above 0.45 (Alfaia et al., 2010). A high ratio of $n-3 / n-6$ is beneficial for reducing the risk of coronary heart diseases, and the ratio has been suggested to be a useful indicator for comparing relative nutritional values of oils (Özparlak, 2013; Olgunoglu and Artar 2016). In the present study the PUFA/SFA ratio was found to be 0.30 and 0.26 for snail meats from Adana and Sinop respectively. The ratio of n-3/n- 6 was higher in snail from Adana (0.63) than the snail meat from Sinop (0.44).

In our study, in contrast to previous reports, the examined snails demonstrated a high content of fat. Besides, the ratio of PUFA/SFA was lower in $H$. lucorum than those recommended for nutritional. However, the ratio of $n-3 / n-6$ and the amount of PUFAs were found in good range in snail meat from Adana than Sinop. It could be demonstrated that the snail meat from Adana is a desirable item in human diet when the levels of $n 3 / n 6$ and PUFA/SFA ratios were considered to snail meat from Sinop.

\section{References}

Abdulmawjood A, Bülte M. 2001. Snail species identification by RFLP-PCR and designing of species-specific oligonucleotide primers. Food Chemistry and Toxicology 66:9, 1287-1293. 
Alfaia CM, Alves SP, Lopes AF, Fernandes MJ, Costa AS, Fontes CM, Castro ML, Bessa RJ, Prates JA. 2010. Effect of cooking methods on fatty acids, conjugated isomers of linoleic acid and nutritional quality of beef intramuscular fat. Meat Science 84: 769-777.

AOAC. 1995. Method 925.10, 920.39, 925.10 and 990.03, Association of official analytical chemists, Official methods of analysis, 16 th ed., Washington.

Baki B. 2010. Biology, economy and legal hunting and exporting legislations of a terrestrial snail in Turkey: Helix lucorum (L., 1758). Journal of Agricultural Faculty of Uludag University, 24(1): 109-114.

Baltic MO D. 2005. Snail meat-significance and consumtion. Veterinarski Glasnik. 59(3-4): 463 - 474.

Citil OB, Tekeli Y, Danahaliloglu H, Bucak S. 2014. The effects of seasons on cholesterol content and fatty acid compositions of muscle of Helix Aspersa living in Konya, Turkey. African Journal of Traditional, Complementary and Alternative Medicines. 11(6): 53-56.

Çelik MY, Duman MB, Sariipek M, Gören GU, Öztürk DK, Kocatepe D, Karayücel S. 2017. Comparison study of aminoacid composition between wild and farmed land snails. Central Anatolia Region, Agriculture and Food Congress Turkey,

Ekin İ, Başhan M, Şeşen R, Kızmaz V. 2015. Determination of fatty acids from phospholipid subclasses in the total body and cephalopedal tissues from edible snail Helix lucorum. Turkish Journal of Biochemistry. 40(2): 132-139.

Fagbuaro O, Oso JA, Edward JB, Ogunleye RF. 2006. Nutritional status of four species of giant land snails in Nigeria Journal of Zhejiang University Science B 7(9): 686689.

Göçer M, Olgunoglu IA, Olgunoglu MP. 2018. A study on fatty acid profile and some major mineral contents of sea cucumber (Holothuria (platyperona) sanctori) from Mediterranean Sea (Turkey). Food Science and Quality Management. 72: 1-5.

Gül K, Fenercioğlu H. 1992. Study on determination of the differences occured during holding and processing and of chemical composition of snails obtained from Adana Region. Gida, 17

Haider MS, Sultana R, Jamil K, Lakht-e-Zehra TOM, Shirin K, Afzal W. 2015. A study on proximate composition, amino acid profile, fatty acid profile and some mineral contents in two species of sea cucumber. The Journal of Animal \& Plant Sciences, 25(1): 168-175.

Ikauniece D, Jemeljanovs A, Sterna V, Strazdina V. 2014. Evaluation of nutrition value of Roman snail's (Helix Pomatia) meat obtained in Latvia. Foodbalt, 28-31.

Lukong CB, Ezebuo FC, Verla AW. 2012. Characterization of the Major Essential Elements in the Haemolymph of the Giant African Land Snail (Achatina achatina) During Aestivation. Biosciences Biotechnology Research Asia. 9(2): 577-584.

Milinsk MC, Grac-As Padre Roseli das, Hayashi C, Oliveira C C. de, Visentainera, JV, Souza N, Evela'zio de, Matsushita M. 2006. Effects of feed protein and lipid contents on fatty acid profile of snail (Helix aspersa maxima) meat. Journal of Food Composition and Analysis. 19: 212-216.
Mumladze L. 2013. Shell size differences in Helix lucorum Linnaeus, 1758 (Mollusca: Gastropoda) between natural and urban environments. Turkish Journal of Zoology. 37: 1-6.

Olgunoglu IA, Olgunoglu MP. 2008. Amino acid composotion of edible land snail (Helix lucorum Linneaus, 1758). Uludag Univ. J. Fac. Vet. Med. 27(1-2): 35-39.

Olgunoglu IA, Olgunoglu MP. 2009. Preparation of frozen buttered snail (Helix lucorum Linnaeus, 1758) meat and analyses of food labels. BIBAD, 2(1): 35-39.

Olgunoglu İA, Olgunoglu MP. Artar E. 2011. Seasonal changes in biochemical composition and meat yield of Shabut (Barbus grypus, Heckel 1843). Iranian Journal of Fisheries Sciences 10(1): 183-189.

Olgunoglu 2013. Seasonal variation of the fatty acid composition in the muscle of Mesopotamian Catfish (Silurus Triostegus, Heckel, 1843) from Atatürk Dam Lake (Turkey, Adiyaman). Advences in Food Science. 35(3): 126-130.

Olgunoglu İA, Artar E. 2016. The fatty acid profiles in the muscle tissues of four benthic fish species from Northeastern Mediterranean Sea of Turkey. Research Journal of Biotechnology 11(9): 71-74.

Osibona AO, Kusemiju K, Akande GR. 2009. Proximate composition and fatty acids profile of the African Catfish Clarias gariepinus. acta SATECH 3(1): 85 - 89.

Özogul Y, Özogul F, Olgunoglu IA. 2005. Fatty acid profile and mineral content of the wild snail (Helix pomatia) from the region of the south of the Turkey. European Food Research and Technology. 221: 547-549.

Özparlak H. 2013. Effect of seasons on fatty acid composition and n-3/n-6 ratios of muscle lipids of some fish species in Apa Dam Lake, Turkey. Pakistan Journal of Zoology. 45(4): 1027-1033.

Pasdaran A, Selamoglu Z, Pasdaran A. 2017a. Fatty Acids Composition of Alburnus chalcoides Güldenstädt "Caspian shemaya" or "Koli mahi" Meat. 1st International Symposium on Limnology and Freshwater Fisheries. 4-6 October 2017 Eğirdir, Isparta - Turkey. Abstract ID: FPT040.

Pasdaran A, Selamoglu Z, Pasdaran A. 2017b. Fish Species of Caspian and Ponto-Caspian Region as a Valuable Source of Unsaturated Fatty Acids.1st International Symposium on Limnology and Freshwater Fisheries. 4-6 October 2017 Eğirdir, Isparta - Turkey. Abstract ID: FPT-041

Saglam N, Gokhan HB. 2006. Investigation of endohelmintes in snail (Helix lucorum, Linneaus, 1758) living in Keban Region of Elaziğ. E.U. Journal of Fisheries \& Aquatic Sciences, 23:1/2;287-289.

Sutharshiny S, Sivashanthini K. 2011. Proximate composition of three species of Scomberoides fish from Sri Lankan Waters. Asian Journal of Clinical Nutrition 3(3): 103-111.

Uboh FE, Williams IO, Essien NC. 2014. Effect of processing on the proximate and mineral composition of Archachatina marginata and Achatina achatina. Food and Public Health, 4(1): 10-14.

Yıldırım M Z, Kebapcı Ü, Gümüş B A. 2004. Edible snails (Terrestrial) of Turkey. Turkish Journal of Zoology. 28: 329-335.

Zarai Z, Frikha F, Balti R, Miled N, Gargouri Y, Mejdoub H. 2011. Nutrient composition of themarine snail (Hexaplex trunculus) from the Tunisian Mediterranean coasts. Journal of the Science of Food and Agriculture. 91: 1265-1270. 